\title{
Sharia Corporate Governance and Reputation Effects on Customer Trust in Islamic Bank (Survey on BJB Syariah KCP Cimahi)
}

Evita Nurul Rusady, Girang Razati dan Suci Aprilliani Utami.

Universitas Pendidikan Indonesia

E-mail:_evitanurulrusady@ student.upi.edu,girangrazati@upi.edu, suci.avril@upi.edu

Abstract. The city of Cimahi is ranked the lowest in wealth and deposits compared to eight cities in West Java Province, which confirms that the level of public trust in Islamic banks is still low. The low customer confidence is that the Sharia Corporate Governance has not been maximized, as evidenced by IRTI's research results showing that GCG implementation has not been implemented well in Islamic banks in various countries and fails to apply sharia principles $85 \%$. Sharia Corporate Governance (SCG) is a combination of two theories, namely Good Corporate Governance (GCG) and the theory of Sharia Compliance. The implementation of SCG in Islamic banks is based on six principles: transparency, accountability, accountability, professionalism, and fairness and implementation of compliance shariah. Sharia Corporate Governance (SCG) is also referred to as a system, regulation, and process used to realize a compliance culture in managing Islamic banking risk and monitoring, regulating, and encouraging its performance efficiently to generate sustainable added value for stakeholders in the long term following sharia principles. This study aims to determine the effect of the application of SCG and reputation on customer trust in Islamic banks. The population in this study is the customer of BJB Syariah KCP Cimahi. The sampling technique in this study was simple random sampling with a sample of 210 respondents. The method used in this research is explanatory. The data analysis technique used is the multiple linear regression method. The results of the research designation that the implementation of Sharia Corporate Governance and reputation simultaneously affect customer trust, and this will have an impact on increasing the market share of Islamic banks.

Keywords. Sharia Corporate Governance, Reputation, Trust.

\section{INTRODUCTION}

Islamic banks have a relatively large potential market because, for almost two decades, the development of Islamic banks always showing an increase, but its market share did not show the same result. Banking development sharia recorded in statistical data shows that BUS in West Java in 2018 has assets of Rp. 48,363 billion, DPK Rp. 34,223 billion, and financing of Rp.32,099 billion. This is still low compared to DKI Jakarta, which has assets of Rp.320,049 billion, deposits of Rp.167,449 billion, and financing of Rp. 121,532 billion. The following are statistical data that show assets, Deposits and BUS financing in West Java.

Table 1

Total Financing and DPK city inWest Java

\begin{tabular}{|c|c|c|c|c|c|}
\hline \multirow{2}{*}{ CITY } & \multicolumn{5}{|c|}{$\begin{array}{c}\text { Provided Financing } \\
\text { (in a million } \\
\text { rupiah) }\end{array}$} \\
\cline { 2 - 6 } & $\mathbf{2 0 1 4}$ & $\mathbf{2 0 1 5}$ & $\mathbf{2 0 1 6}$ & $\mathbf{2 0 1 7}$ & $\mathbf{2 0 1 8 ^ { * }}$ \\
\hline Bandung & 9.708 & 11.028 & 10.033 & 13.034 & 12.958 \\
\hline Bogor & 3.190 & 8.249 & 3.166 & 4.156 & 4.171 \\
\hline Sukabumi & 383 & 370 & 377 & 304 & 301 \\
\hline Cirebon & 2.411 & 2.548 & 2.428 & 3.010 & 2.983 \\
\hline Tasik & 1.494 & 1.681 & 1.515 & 2.018 & 1.970 \\
\hline Cimahi & 124 & 218 & 152 & 141 & 142 \\
\hline
\end{tabular}




\begin{tabular}{|c|c|c|c|c|c|}
\hline \multirow{2}{*}{ Depok } & 994 & 1.148 & 1.030 & 1.574 & 1.563 \\
\hline \multirow{2}{*}{ Bekasi } & 5.105 & 5.179 & 4.851 & 4.995 & 4.872 \\
\cline { 2 - 6 } & \multicolumn{5}{|c|}{ (Juta Rupiah) } \\
\hline \multirow{2}{*}{ Bandung } & $\mathbf{2 0 1 4}$ & $\mathbf{2 0 1 5}$ & $\mathbf{2 0 1 6}$ & $\mathbf{2 0 1 7}$ & $\mathbf{2 0 1 8}$ \\
\hline Bogor & 8.255 & 8.665 & 7.686 & 11.373 & 11.765 \\
\hline Sukabumi & 3.119 & 8.847 & 3.438 & 4.771 & 4.733 \\
\hline Cirebon & 1.651 & 415 & 333 & 422 & 425 \\
\hline Tasik & 837 & 981 & 825 & 1.142 & 1.095 \\
\hline Cimahi & 192 & 298 & 213 & 254 & 257 \\
\hline Depok & 1.579 & 1.780 & 1.634 & 2.732 & 2.762 \\
\hline Bekasi & 5.991 & 6.444 & 5.628 & 8.742 & 8.561 \\
\hline
\end{tabular}

Source: Bank Indonesia, Sharia Banking Statistic (2018)

Table 1 shows eight cities in West Java Province; Cimahi City is the lowest rank in the activities of the administration and Third Party Fund, which makes public trust in Islamic banks still low. Besides that, other factors are causing low public trust: Islamic banks' low reputation due to fraud committed by one of the Islamic banks, namely BJB Syariah branch Braga where the President Director is involved in the case suspected corruption of BJB Syariah credit to debtors on behalf of PT. Hatsuka Sarana Karya to finance the Garut Super Blok project for construction of 161 shop houses in Garut (Sohuturon, 2017). As a result of violations committed by the Director, This BJB Syariah indicates the declining reputation of Islamic banks in the city of Cimahi.

Whereas if we look at the socio-religious aspects of the city of Cimahi, it has a huge market potential because Moslem, namely 93.97\%, dominate the people of Cimahi City. Cimahi City also has a large workforce of $64.09 \%$ of the total population (Statistik, Badan Pusat Statistik Kota Cimahi, 2018). These conditions show the magnitude of the potential development of Islamic banking in the City of Cimahi, which until now has not been thoroughly carried out by the Islamic banking industry optimally.

Based on the results of Wardayati (2011) research, several factors have caused the market share of Islamic banking to still low, among others: (1) the community's understanding of Islamic banking operations; (2) limited quality of resources; (3) less innovative in developing sharia-based products.

Other causes are also due to the lack of implementation of good corporate governance (GCG). Good corporate governance (GCG) is a system that regulates and controls companies that create added value for all stakeholders (Monks, 2003). According to IRTI's research results, the implementation of GCG has not been implemented well in Islamic banking in various countries. According to Chapra (2002), failure in applying sharia principles will make customers move to another bank by $85 \%$. Therefore the implementation of GCG and the application of sharia principles, known as Shariah Corporate Governance, is a necessity for Islamic banks to improve reputation and maintain customer trust in Islamic banks and protect the interests of stakeholders in order to maintain a reputation or image of a healthy and trusted Islamic bank.

The principles of Corporate Governance in the Islamic Perspective are realized through the Shariah framework in the conduct of business, justice, and equality for the benefit of being oriented to Allah SWT as the sole owner and authority in the world. Good Corporate Governance is related to the hadith of the Prophet Muhammad, which was narrated by Aisyah r.a, which means "Surely Allah likes when someone does something good done."

And the verse of the Qur'an, as in the létter Al-Maidah verse $8:$

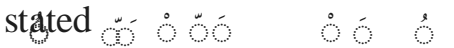

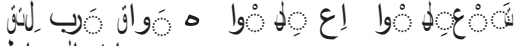

$$
\begin{aligned}
& \text { وى وانموالئي ال }
\end{aligned}
$$

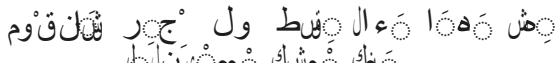

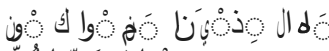

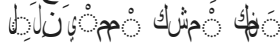

$$
\begin{aligned}
& \text { لे }
\end{aligned}
$$

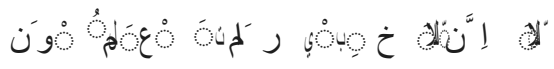


"O ye who believe! Be steadfast witnesses for Allah in equity, and let not hatred of any people seduce you that ye deal not justly. Deal justly, that is nearer to your duty. Observe your duty to Allah. Lo! Allah is Informed of what ye do." (QS. 5:8).

Reputation is an award obtained by the company because of the advantages that exist in the company, such as the ability possessed by the company, so the company will continue to be able to develop itself (Hebrig., 1995).

Trust, in general, is seen as a fundamental element for the success of a company's relationship. Without trust or relationships, the company will not survive for an extended period (Rosidah, 2011). According to Mayer et al. (1995), which shapes one's trust in others consists of three factors, namely ability, benevolence, and integrity.

Bank BJB Syariah Sub-branch Office of Cimahi is one of the Sharia Commercial Banks, which has helped many communities raise funds and finance the community in Cimahi. BJB Syariah has proven to survive in an unstable economic condition in Cimahi. Based on the description, the author is interested in conducting a study on "The Effect of Shariah Corporate Governance and Reputation on Customer Trust (Case Study in BJB Syariah KCP Cimahi)."

\section{LITERATURE REVIEW THEORETICAL FOUNDATION}

\section{Shariah Corporate Governance}

The term shariah corporate governance in this research is developing the concept of corporate governance and shariah compliance. According to the Forum for Governance in Indonesia (FCGI) in Wardayati (2011), Good Corporate Governance is defined as a set of rules that establish relationships between stakeholders, administrators, creditors, governments, employees, and other internal and external stakeholders. According to Junusi (2012), shariah compliance is the compliance of Islamic banks towards sharia principles. So that sharia corporate governance is a system, regulation, and process that is used to realize a compliance culture in managing the risk of Islamic banking and monitoring, regulating, and encouraging its performance efficiently to produce sustainable added value for stakeholders in the long run following the principles sharia.

In this study, sharia corporate governance is the development of the concept of good corporate governance transparency, accountability, responsibility, independence and fairness, and shariah compliance.

a. Transparency, namely openness in expressing material and relevant information and openness in the decision-making process (Wardayati, 2011).

b. Accountability, namely clarity of functions, structures, systems, and accountability of corporate organs so that company management is carried out effectively (Kaihatu, 2006).

c. Responsibility/accountability is conformity in managing a company against applicable laws and regulations (Arbiana, 2012).

d. Independence is a condition where the company is managed professionally without conflict of interest and influence/pressure from the management that is not following the applicable rules and regulations and sound corporate principles (Kaihatu, 2006).

e. Justice often referred to as fairness, is justice and equality in fulfilling the rights of stakeholders that arise based on agreements and applicable legislation. Fairness refers to equal treatment of stakeholders following the criteria and proportions that should be (Wahananto, 2009).

f. Shariah compliance is the compliance of Islamic banks with sharia principles. 


\section{Reputation}

Paul Hebrig (1995) Reputation is an award obtained by the company because of the advantages that exist in the company, such as the ability possessed by the company, so that the company will continue to develop itself to continue to be able to create new things for meeting needs consumer. Companies can build a variety of reputations, such as quality reputation, marketing reputation, product innovation reputation, and so on. A company's reputation will decline when it fails to meet what the market requires (Paul Hebrig J. M., 1994). Hybrid, Milewicz, and Golden also stated that the company's reputation can be seen from its competency and its superiority compared to other competing companies.

Whereas Moorman and Miner (1997) prove that the company's success can be achieved maximally if the company focuses on its core business because the focus will show its core competencies so that customers trust the company's expertise reflected in their knowledge and the company's experience in the business that it has run.

Based on the things that have been conveyed by the researchers above, it can be concluded that the dimensions of company reputation that can be used in this study are:
a. Company Competence
b. Company excellence
c. Customer trust
d. Company experience

\section{Customer Trust}

Trust in general is seen as a fundamental element for the success of a company's relationship. Without trust or relationship, the company will not survive for an extended period (Rosidah, 2011). According to Mayer et al. (1995), the factors that make up trust are three factors: ability, benevolence, and integrity. These three factors can be explained as follows:

a. Ability

Ability refers to the competencies and characteristics of the seller / organization in influencing and authorizing specific areas. In this case, how the seller can provide, serve, and secure transactions from other parties. This means that consumers get guaranteed satisfaction and security from the seller in making transactions.

b. Benevolence

Benevolence is the willingness of sellers to provide mutually beneficial satisfaction between themselves and consumers. The profit obtained by the seller can be maximized, but customer satisfaction is also high. The seller is not merely pursuing maximum profit, but also significantly attention in realizing customer satisfaction.

c. Integrity

Integrity is related to how the behavior or habits of the seller in running his business. The information provided to consumers is accurate or not following the facts. The quality of products sold is reliable or not.

\section{PREVIOUS RESEARCH}

Juliana conducted the research et al. (2018) entitled The Growth and Equity of Economic in the Perspective of Politics in Islamic Economic show that there was still unbalance of income equity that affected citizens to receive shared prosperity. The findings from the research show the economic growth according to Islamic Economy is not only related to the material development of life standards. Besides, the ideal economic growth will be able to be created optimally and affect the equity of the economy if it uses the politic of the Islamic economy through direct and indirect strategies. The research by ALMIZAN (2016) entitled Economy Development in the Perspective of 
Islamic Economy describes economic development as one of the strategies to achieve the desired goal of the nation. The goal includes how poverty, unemployment, economy, and social disparity are solved to realize humanity's prosperity. Further, economic development is described as the development of human maturity where material development could not be avoided and supported by spiritual maturity. The most crucial purpose from the growth of employment added by trustworthy skills will become work with high quality, economic stability, fair distribution, and environment friendly. Islamic comprehensive economy development has the characteristic of spiritual, moral, material, and the activity tends to be multidimensional. Thus, businesses can balance the factors and eliminate inequality.

\section{RESEARCH METHODOLOGY}

The method used for data collection in this study uses explanatory methods with quantitative approaches. In addition, the research design used was explanatory. The object of research used are three variables, namely corporate governance (X1) and reputation (X2) as independent variables), as well as customer trust as the dependent variable $(\mathrm{Y})$. The population in this study is the customer of BJB Syariah KCP Cimahi. The sampling technique in this study was simple random sampling with a sample of 210 respondents.

This study uses data analysis techniques using multiple linear regression with an F-test t-test and tests the coefficient of determination (R2). The research was tested using the classic assumption test, namely the normality, heteroscedasticity, and autocorrelation test. The analytical tool used in SPSS Statistics

22. The aim is to closely study the influence between several independent variables and the dependent variable.

\section{DISCUSSION}

Based on the results of the analysis carried out by the author, the descriptive analysis and interpretation of the overall data from the research results or field findings which include a general description of each research variable, are as follows:

1. General Description of Variables for the Implementation of Sharia Corporate Governance The Calculation of Invested Capital (IC)

Table 2

Respondent's Distribution Based on Customer Assessment of the Application of SCG

\begin{tabular}{lcccc}
\hline & Range & Categories & Frequency & Percentage \\
\hline $88 \leq \mathrm{X}$ & High & 163 & $77.6 \%$ \\
$56 \leq \mathrm{X} \leq 88$ & Medium & 47 & $22.4 \%$ \\
$\mathrm{X}<56$ & Low & - & - \\
\hline & & $\mathbf{2 1 0}$ & $\mathbf{1 0 0 \%}$ \\
\hline
\end{tabular}

Source: Research Data (2018)

Based on the results of the categories in Table 2, it can be seen that the highest frequency of the answers of each respondent is in the high category $(88 \leq \mathrm{X})$, which is 163 respondents. This shows that BJB Syariah customers consider that the application of Sharia Corporate Governance in the KCP BJB Syariah Cimahi is already (very good) high. 


\section{General Description Variable Reputation}

Tabel 3

Distribution of Respondents Based on Reputation Variables

\begin{tabular}{|c|c|c|c|}
\hline Range & Category & Frequency & Percentage \\
\hline $40,3 \leq X$ & High & 171 & $81.4 \%$ \\
\hline $25,7 \leq X \leq 40,3$ & Medium & 38 & $18,1 \%$ \\
\hline$X<25,7$ & Low & 1 & $0.5 \%$ \\
\hline & & 210 & $100 \%$ \\
\hline
\end{tabular}

Source: Research Data (2018)

Based on the results of the categories in Table 3, it can be seen that the highest frequency of the answers of each respondent is in the high category $(40.3 \leq \mathrm{X})$, which is 171 respondents. This shows that BJB Syriah KCP Cimahi customers assess the reputation of the KCP Cimahi Syariah BJB is high.

\section{General Description Variable Customer Trust}

Table 1

Distribution of Respondents Based on Customer Trust Variable

\begin{tabular}{|c|c|c|c|}
\hline Range & Category & Frequency & Percentage \\
\hline $40,3 \leq X$ & High & 171 & $81.4 \%$ \\
\hline $25,7 \leq X \leq 40,3$ & Medium & 38 & $18,1 \%$ \\
\hline$X<25,7$ & Low & 1 & $0.5 \%$ \\
\hline & $x^{2}$ & 210 & $100 \%$ \\
\hline
\end{tabular}

Source: Research Data (2018)

Based on the results of the categories in Table 4, it can be seen that the highest frequency of the answers of each respondent is in the high category $(40.3 \leq \mathrm{X})$, which is 171 respondents. This shows that BJB Syriah KCP Cimahi customers assess the reputation of the KCP Cimahi Syariah BJB as high.

\section{The Classic Assumption Test}

The classic assumption test is done to ensure that the regression equation obtained will have accuracy. The classic assumption test carried out in this study was the normality test, multicollinearity test, heteroscedasticity test, and autocratic test. Testing is done using SPSS Statistics 22, with the following results:

\section{Normality Test}

In this study, the normality test is used by looking at Probability Distribution Function (PDF), which compares the cumulative distribution of actual data with cumulative distribution from average data.

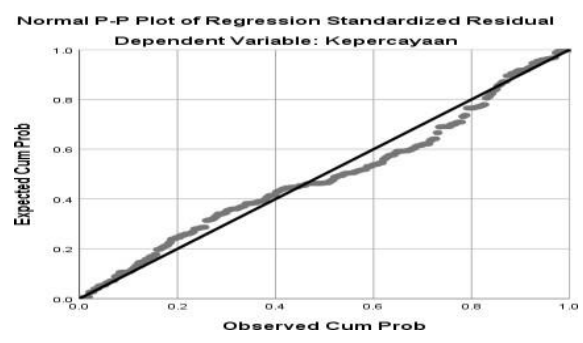

Picture 1

Normality Test Result 
Based on Figure 4.3, it can be seen that the results of the test are generally distributed because the points in the image follow the direction of the diagonal line.

\section{Multicollinearity Test}

Provisions for decision making to determine whether or not the data is exposed to multicollinearity is to use the efficiency test by looking at the Tolerance and VIF values.

Table 2

\section{Multicollinearity Test Result}

\begin{tabular}{lccc}
\hline \multicolumn{1}{c}{ Variable } & Tolerance & Collinearity Statistic \\
VIF & \\
\hline Sharia Corporate Governance & & 0,887 & 1,127 \\
Reputasi & 0,887 & 1,127 \\
\hline Source: Research Data $(2018)$ & &
\end{tabular}

Source: Research Data (2018)

Based on the table above, the multicollinearity test results show the tolerance value of all variables greater than 0.10 from the VIF value smaller than 10.00. Thus it can be concluded that this research data has fulfilled the requirements of no multicollinearity.

\section{Heteroscedasticity Test}

In this study, the way to detect Heteroscedasticity is to look at a scatter plot graph between the predicted value of the dependent variable (ZPRED) and its residual value (SSID).

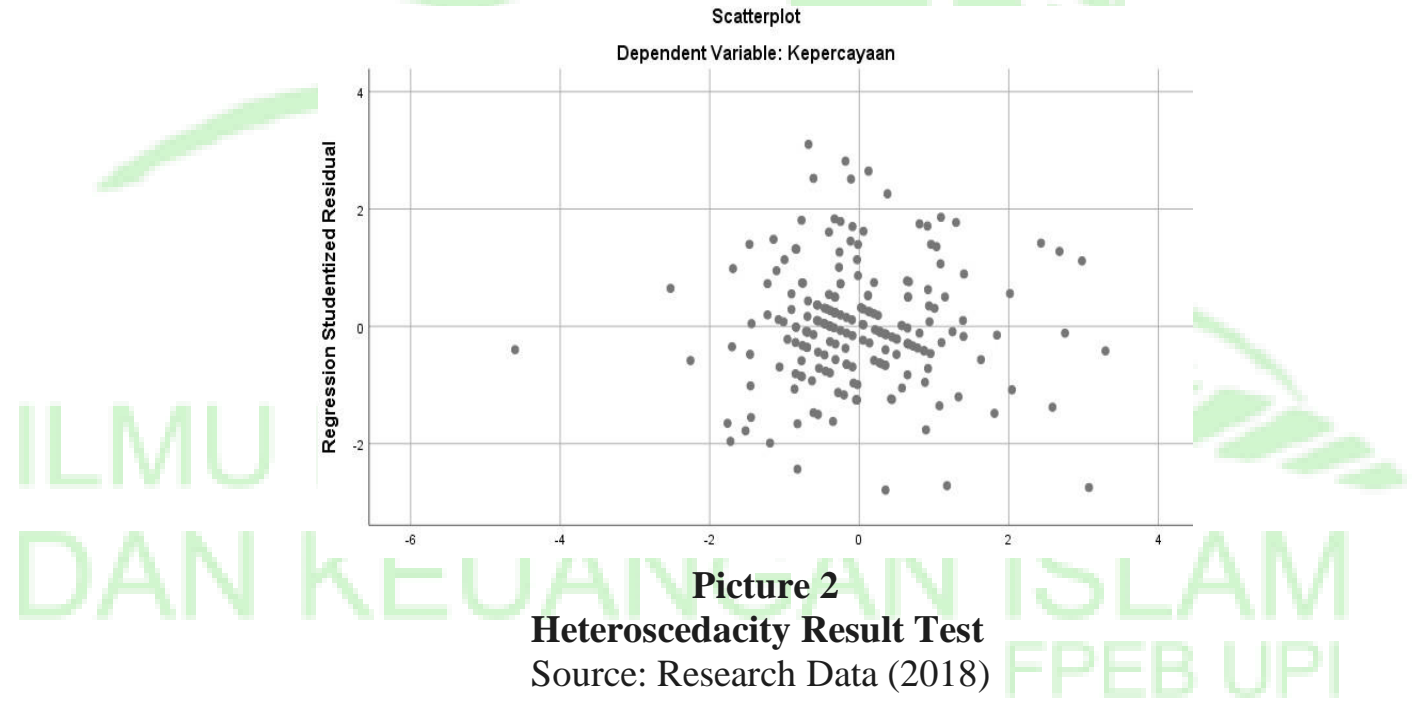

Based on Figure 4.4, it can be seen that there is no clear pattern, as well as spreading points above and below the number 0 on the $\mathrm{Y}$ axis; it can be concluded that there was no heteroscedasticity in this study.

\section{Autocorrelation Test}

Autocorrelation testing is done by the Watson Durbin test. How to detect it is by placing a value (d) on the Watson Durbin size table, it will be known whether the value lies in negative autocorrelation, doubtful autocorrelation, or no correlation area. The autocorrelation results will be described as follows:

Table 3

Autocorrelation Result Test

\begin{tabular}{|c|c|c|c|c|c|}
\hline \multicolumn{6}{|c|}{ Model Summary } \\
\hline Model & $\mathrm{R}$ & R Square & Adjusted R Square & Std. Error of the Estimate & Durbin-Watson \\
\hline 1 & $0.479^{\mathrm{a}}$ & 0.230 & 0.222 & 3.774 & 1.864 \\
\hline \multicolumn{6}{|c|}{ a. Predictors: (Constant), Reputasi, SCG } \\
\hline b. Dep & ariable: $\mathrm{r}$ & & & & \\
\hline
\end{tabular}

Source: Research Data (2018) 
Based on table 6 the Durbin Watson stat value is 1,864 with the number of observers 210 and the number $\mathrm{k}=2$ (where $\mathrm{k}$ is the number of independent variables). Durbin Watson's measuring table can be seen as follows:

\begin{tabular}{|c|c|c|c|c|}
\hline $\begin{array}{l}\text { Postive } \\
\text { Autocorrelation }\end{array}$ & Inconclusive & & Inconclusive & $\begin{array}{l}\text { Positive } \\
\text { Autocorrelation }\end{array}$ \\
\hline 0 & $\mathrm{dL} \quad \mathrm{du}$ & $4-\mathrm{dL}$ & $4-d u$ & 4 \\
\hline 0 & 1.7481 .788 & 2.252 & 2.212 & 4 \\
\hline
\end{tabular}

Based on the picture above, the value of $d=1.846$ is located in the area of "no autocorrelation" so that it can be concluded that this study is free from autocorrelation.

\section{Multiple Linear Regression Analysis}

Based on the result of the analysis obtained, the multiple regression equation is as follows:

Testing the hypothesis through this t-test is carried out with a significance level of $5 \%$ or 0.05 at a confidence level of $95 \%$ and a degree of freedom value $(\mathrm{df}=\mathrm{n}-\mathrm{k}=210-2=208)$ so that the $\mathrm{t}$ table value is 1.971 .

Table 4

Result t-test Variabel Sharia Corporate Governance

\begin{tabular}{cccccc}
\hline Koefisien & t-hitung & t-table & Probabilitas & Keputusan & Keterangan \\
\hline 0,151 & 4,555 & 1.971 & 0,000 & Menerima $\mathrm{H}_{1}$ & Significance \\
\hline
\end{tabular}

\section{Hypothesis Testing}

1. Corporate Governance Sharia Has Significant Effects on Customer Trust

Based on the estimation results found in Table 7, the significance level of corporate governance sharia influence on customer trust is $0,000<0,05$, which means significant. This indicates that corporate governance sharia has a significant effect on customer trust where the coefficient value obtained is 0.151 , which means that when sharia corporate governance has increased by one unit, the customer trust will increase by 0.151 calculation units assuming ceteris paribus. Thus, the results of this study accept $\mathrm{H} 1$ in the hypothesis because the results of the study show that corporate governance sharia has a significant effect on customer trust.

This is in line with the research conducted by Ilhami (2009) that community trust and confidence in Islamic banks are based and maintained through the implementation of the principles of the Islamic law that are adapted in the operational rules of the institution.

2. Reputation Has Significant Effects on Customer Confidence.

\section{Table 5}

\section{Result t-Test Variabel Reputation}

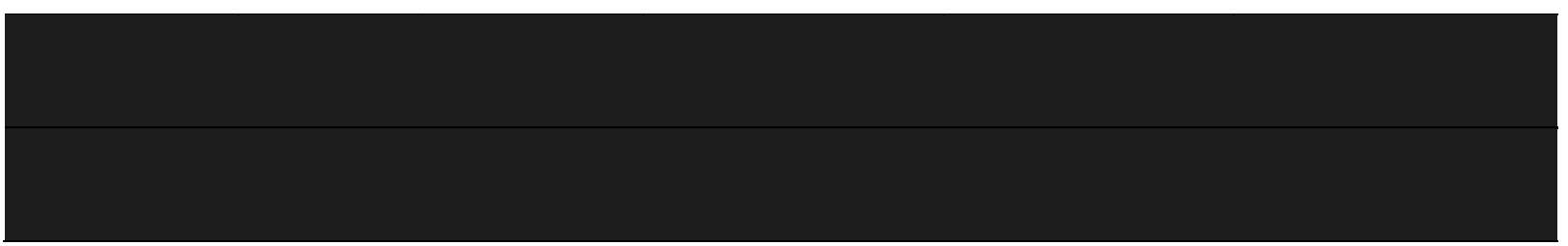

Source: Research Data (2018) 


$$
\mathrm{Y}=12,033+0,151 \mathrm{X}_{1}+0,315 \mathrm{X}_{2}+\mathrm{e}
$$

The estimation results found in Table 8 show that the significance level is $0,000<0,05$, which means significant. This indicates that the company's reputation has a significant effect on customer trust where the coefficient value obtained is 0.315 , which means that when the company's reputation increases by one unit, the customer's trust will increase by 0.315 units of calculation, assuming ceteris paribus. Thus, the results of this study accept $\mathrm{H} 1$ in the hypothesis because the results of the study show that reputation has a significant effect on customer trust. The same thing was started by Aswati (2013). The results of his research also stated that reputation is positively related to trust.

3. The effects of Sharia Corporate Governance and Reputation on Customer Trust.

Table 6

Result Test - F

\begin{tabular}{|c|c|c|c|c|}
\hline F-hitung & F-tabel & Probability & $\underline{\text { Keputusan }}$ & Keterangan \\
\hline 30,842 & 3,04 & 0,000 & Menerima $\mathrm{H}_{\mathrm{a}}$ & Significance \\
\hline
\end{tabular}

Source: Research Data (2018)

Based on Table 9 it can be seen that $F$ count $>\mathrm{F}$ table is $30.824>3.04$ and $\mathrm{p}<\alpha$, which is 0,000 $<0.05$, it can be concluded that $\mathrm{Ha}$ is accepted, or all independent variables $(\mathrm{X})$, namely Sharia Corporate Governance and Reputation, simultaneously affect the dependent variable (Y), that is, customer trust.

Determination Coefficient $\mathbf{R}^{2}$

Table 7

Determination Coefficient Test ResultR ${ }^{2}$

\begin{tabular}{lc}
\hline R-squared & 0,230 \\
Adjusted R-squared & 0,222 \\
Std. Error of the Estimate & 3,774 \\
\hline Source: Research Data (2018) &
\end{tabular}

Based on Table 4.38 shows that the Adjusted R-squared value is 0.222 . This shows that 22.2 percent of customer trust can be explained by sharia corporate governance and reputation. While the remaining 77.8 percent is explained by other variables outside the model that were not included in the study.

\section{CLOSING \\ Conclusion}

Based on the research that has been conducted on the KCP Cimahi Syariah BJB customers, it can be concluded that the application of Sharia Corporate Governance in the BJB Syariah KCP Cimahi is included in the high category, this is because the customers consider KCP Cimahi Syariah BJB have implemented corporate governance very well. Next, the reputation of BJB KCP Cimahi is in the high category. This is because the customers consider that the KCP Cimahi Syariah BJB has the competency, excellence, and good experience. Customer trust in BJB Syariah KCP Cimahi is in the high category, and this is because customers consider that KCP Cimahi Syariah BJB is a bank that can provide, serve, secure customer transactions well. Customers obtain a mutually beneficial satisfaction guarantee for both the bank and customers and banks have good integrity.

The application of Sharia Corporate Governance (SCG) and reputation has a significant and simultaneous effect on trust. This shows that the more compliant Islamic banks towards the SCG and the higher the reputation of Islamic banks, the customers' trust in Islamic banks also increases. Increasing customer confidence in Islamic banks in the long term will increase customer loyalty and increase the market share of Islamic banks. 


\section{Suggestion}

1. For infrastructure sector companies, because many factors affect the value of EVA, it can use the following strategies in order to maintain or even increase the value of EVA in the next period, including:

a. It can be more efficient in the capital spent by the company to get capital for the company.

b. Can maintain the company's profit/profit value.

c. Always provide clear and detailed information to all investors regarding the condition of the company.

2. For investors, to be more careful if you want to invest in a company, it would be nice to first measure the company's performance.

3. For researchers next, to increase the period of the period so that the company's performance can be broader.

\section{REFERENCE}

A. G Robert Monks, M. (2003). Corporate Governance 3 Edition. Blackwell Edition.

Arbiana. (2012). Penerapan Good Corporate Governance Pada Perbankan Indonesia. Jurnal Akuntansi Unesa Vol. 1 No. 1, 15-30.

Aswati, L. (2013). Analisis Pengaruh Komunikasi, Kepuasan Atas Kebijakan Perusahaan Dan Kemampuan Tenaga Penjual Terhadap Kepercayaan Pengecer Pada Perusahaan (Studi Kasus Pada Pt Dharma Guna Wibawa Di Kalimantan). Jurnal Manajemen Dan Bisnis Vol.2 No.1.

Bill Foster, K. R. (2001). Pembinaan Untuk Meningkatkan Kinerja Karyawan. Jakarta: Ppm.

Chapra, U. (2002). Corporate Governance In Islamic Financial Institution. Occasional Paper No.6, 5867.

Christine Moorman, A. S. (1997). The Impact Of Organization Memory On New Product Performance And Creativity. Journal Of Marketing Vol. 34.

Ilahami, H. (2009). Pertanggungjawaban Dewan Pengurus Syariah Sebagai Otoritas Pengawas Kepatuhan Syariah Bagi Bank Syariah. Mimbar Hukum Vol. 21 No. 3, 409 - 628.

Junusi, R. E. (2012). Implementasi Syariah Governance Serta Implikasinya Terhadap Reputasi Dan Kepercayaan Bank Syariah. Paper Di Presentasikan Di Aicis Surabaya.

Kaihatu, T. S. (2006). Good Corporate Governance Dan Penerapannya Di Indonesia. Jurnal Manajemen Dan Kewirausahaan, Vol.8, No. 1, 1-9.

Paul Hebrig, J. M. (1994). A Model Of Reputation Building And Destruction. Journal Of Business Research Vol.31 No.1, 23-31.

Paul Hebrig, J. M. (1995). The Relationship Of Reputation And Credibility To Brand Succes. The Journal Of Consumer Marketing Vol.12 No.4, 5 - 10.

Roger C. Mayer, J. H., \& Schoorman, F. D. (1995). An Integrative Model Of Organizational Trust. The Academy Of Management Review Vol. 20 No.3, 709 - 734.

Rosidah, C. (2011). Pengaruh Reputasi Perusahaan Dan Kepercayaan Terhadap Loyalitas A. G Robert Monks, M. (2003). Corprate Governance 3 Edition. Blackwell Edition. 
Arbiana. (2012). Penerapan Good Corporate Governance Pada Perbankan Indonesia. Jurnal Akuntansi Unesa Vol. 1 No. 1, 15-30.

Aswati, L. (2013). Analisis Pengaruh Komunikasi, Kepuasan Atas Kebijakan Perusahaan Dan Kemampuan Tenaga Penjual Terhadap Kepercayaan Pengecer Pada Perusahaan (Studi Kasus Pada Pt Dharma Guna Wibawa Di Kalimantan). Jurnal Manajemen Dan Bisnis Vol.2 No.1.

Bill Foster, K. R. (2001). Pembinaan Untuk Meningkatkan Kinerja Karyawan. Jakarta: Ppm.

Chapra, U. (2002). Corporate Governance In Islamic Financial Institution. Occasional Paper No.6, 5867.

Christine Moorman, A. S. (1997). The Impact Of Organization Memory On New Product Performance And Creativity. Journal Of Marketing Vol. 34.

Ilahami, H. (2009). Pertanggungjawaban Dewan Pengurus Syariah Sebagai Otoritas Pengawas Kepatuhan Syariah Bagi Bank Syariah. Mimbar Hukum Vol. 21 No. 3, 409 - 628.

Junusi, R. E. (2012). Implementasi Syariah Governance Serta Implikasinya Terhadap Reputasi Dan Kepercayaan Bank Syariah. Paper Di Presentasikan Di Aicis Surabaya.

Kaihatu, T. S. (2006). Good Corporate Governance Dan Penerapannya Di Indonesia. Jurnal Manajemen Dan Kewirausahaan, Vol.8, No. 1, 1-9.

Paul Hebrig, J. M. (1994). A Model Of Reputation Building And Destruction. Journal Of Business Research Vol.31 No.1, 23-31.

Paul Hebrig, J. M. (1995). The Relationship Of Reputation And Credibility To Brand Succes. The Journal Of Consumer Marketing Vol.12 No.4, 5 - 10.

Roger C. Mayer, J. H., \& Schoorman, F. D. (1995). An Integrative Model Of Organizational Trust. The Academy Of Management Review Vol. 20 No.3, 709 - 734.

Rosidah, C. (2011). Pengaruh Reputasi Perusahaan Dan Kepercayaan Terhadap Loyalitas Nasabahpengguna Atm Pasca Isu Cybercrime (Studi Pada Nasabah Bca Di Surabaya)). Journal Business And Economics.

Sohuturon, M. (2017). Plt Dirut Bjb Syariah Tersangka Kasus Kredit Fiktif. Jakarta: Cnn Indonesia.

Statistik, B. P. (2018, Januari 17). Badan Pusat Statistik Kota Cimahi. Retrieved Juli 19, 2018, From Badan Pusat Statistik Kota Cimahi: Https://Cimahikota.Bps.Go.Id

Suhong Li, B. R. (2006). The Impact Of Suppl Chain Management Practices On Competitive Advantage And Organizational Performance. The International Journal Of Management Science, 107-124.

Wahananto, E. (2009). Penerapan Prinsip-Prinsip Good Corporate Governance Di Bank Syariah. Universitas Brawijaya.

Wardayati, S. M. (2011). Implikasi Shariah Governance Terhadap Reputasi Dan Kepercayaan Bank Syariah. Walisongo, Vol. 19 No.1.

Wardayati, S. M. (2011). Implikasi Shariah Governance Terhadap Reputasi Dan Kepercayaan Bank Syariah. Walisongo Vol.19 No.1. 